\title{
THE FIRST FOSSIL STENOPODIDEAN
}

BY

\author{
FREDERICK R. SCHRAM ${ }^{1}$ ), SHEN YANBIN ${ }^{2}$ ), RONALD VONK ${ }^{1}$ ) \\ and RODNEY S. TAYLOR ${ }^{3}$ ) \\ 1) Zoological Museum, University of Amsterdam, Post Box 94766, \\ NL-1090 GT Amsterdam, The Netherlands \\ 2 ) Institute of Geology and Paleontology, Academia Sinica, 39 East Beijing Road, \\ Nanjing 210008, China \\ 3 ) Department of Earth Sciences, Cambridge University, Downing Street, \\ Cambridge CB2 3EQ, United Kingdom
}

\begin{abstract}
A new genus and species of fossil decapod, Jilinocaris chinensis, is described from the Late Cretaceous of northern China. Although incompletely preserved, enough anatomy is visible to suggest that this species represents the first fossil example of the Stenopodidea and is tentatively assigned to the family Spongicolidae.
\end{abstract}

\section{ZUSAMMENFASSUNG}

Es wird eine neue Gattung und Art eines fossilen Dekapoden, Jilinocaris chinensis, aus der Unterkreide Nordchinas beschrieben. Obwohl nicht vollständig erhalten, reichen die auswertbaren anatomischen Daten aus, um diese Art als erstes fossiles Exemplar der Stenopodidea vorzuschlagen und vorerst der Familie Spongicolidae zuzuordnen.

\section{INTRODUCTION}

The Decapoda constitute one of the major divisions of the Eumalacostraca (Schram, 1986) and have a fossil record that begins in the Late Devonian (Schram et al., 1978). Almost all the major higher taxa within the decapods have had at least some representation out of the fossil record. The earliest dendrobranchiates date from the Permo-Triassic of Madagascar (Glaessner, 1969), but this group is best known as fossils from the extensive fauna of penaeoids from the Jurassic Solnhofen deposits (Münster, 1839; Oppel, 1862). The carideans are relatively rare as fossils, although the earliest include several types identified from the Solnhofen localities (Münster, 1839). Reptantia have the best fossil record of any of the decapods (e.g., see for an overview Glaessner, 1969), as well as the oldest. The 


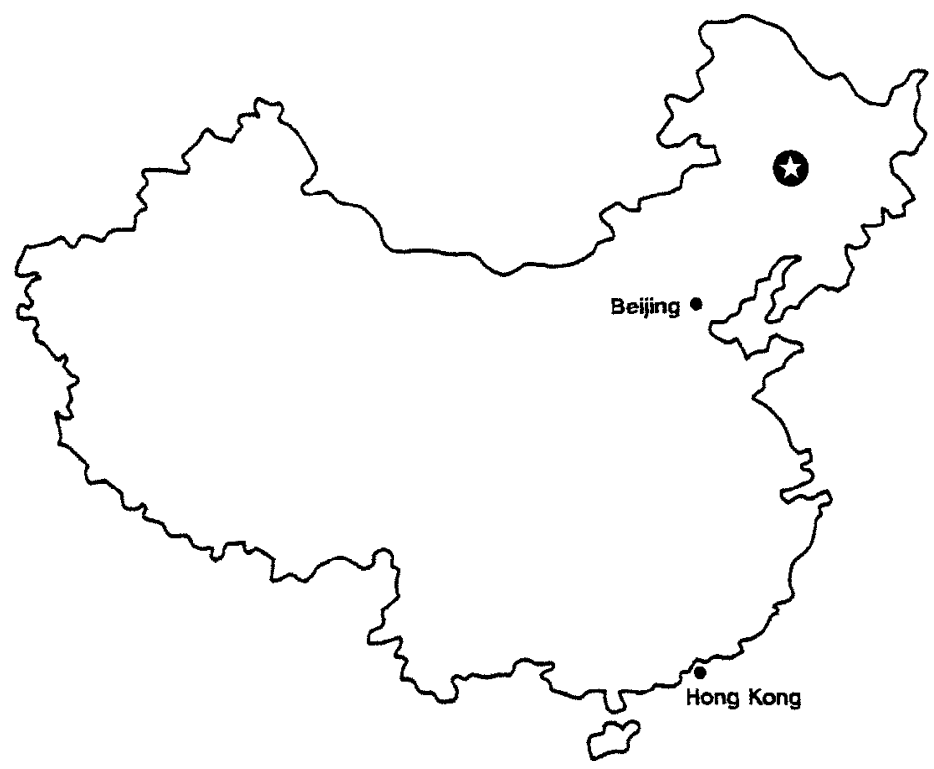

Fig. 1. Map of China showing the Jilinocaris chinensis n. gen., n. sp. locality in Jilin Province, northern China.

first "lobsters" occur in the Devonian of North America (Schram et al., 1978) while the first traces of crayfish are apparently Carboniferous (Hasiotis, in press), and amongst the brachyurans the oldest dromiacean comes from the Pennsylvanian (Upper Carboniferous) of America (Schram \& Mapes, 1984). Thus, of the major groups of decapods, only the Stenopodidea, a small group of "natant" decapods, have until now lacked a fossil record.

We report here a single specimen, IGP no. 126268, collected by Lin Yu-xiu from the Upper Cretaceous, Santonian, Nenjiang Formation located near Hardaling village, Qian Gorlos Mongolzu Zizhixian, Jilin Province, in northern China (fig. 1). The fossil occurs in a light gray to tan muddy siltstone that was weathered. Three conchostracan carapaces, Estherites bifurcatus Zhang \& Chen, 1976, are preserved on the back surface of the thin slab bearing the holotype. These conchostracans are a leading form collected from this formation (Zhang et al., 1976). The Nenjiang Formation is mainly an oil-bearing stratum in the Daqing oil fields and represents a non-marine deposit. 


\section{TAXONOMY}

Family SpongicolidAE Schram, 1986

Jilinocaris $n$. gen.

Diagnosis. - Small to moderate in size. Rostrum short, above a well-developed optic notch. Antennules and antennae robust, with a large broad scale, flagella extremely long. Major pereiopodal cheliped far back on the thorax. Abdominal pleura of the first three pleomeres with thickened rims on their antero-ventral aspects: the first sub-triangular, the second somewhat sub-quadrangular and overlapping the first, and the third as the largest with a anteriorly broadly-rounded extension overlapping the second. Principal point of flexure of the abdomen located at the third pleomere. Narrow fourth through sixth pleomeres apparently lacking welldeveloped pleura and forming a rather straight unit. Uropod long and well developed

Type species. - Jilinocaris chinensis $\mathrm{n}$. sp. by monotypy.

Etymology. - The generic name is derived from a combination of "Jilin", as in Jilin Province, and the common designation for shrimp or crustacean, "caris".

\section{Jilinocaris chinensis sp. nov. (figs. 2-5)}

Holotype. - Specimen number 126268 (figs. 2, 4) in the collections of the Institute of Geology and Paleontology (IGP), Academia Sinica, Nanjing, China. This is a single part of what was a matching part and counterpart. The collector retained the other half, and she has since moved with her whereabouts now unknown.

Description. - The single known individual is approximately $27.5 \mathrm{~mm}$ in length, from the base of the rostrum to the posterior end of the sixth abdominal segment. The carapace is not well preserved, but the remnants of the anterior end indicate a short rostrum above a well-developed optic notch. The main body of the carapace is only vaguely observable.

The antennules and antennae are preserved only in their proximal most aspects. The peduncles appear as robust structures, and the remnants of the scaphocerite of the antenna indicate the presence of a large, broad scale. Remains of the flagella of the antennule extend for some distance from the front end of the thorax and indicate extremely long structures.

The proximal-most parts of the pereiopods are preserved, but not beyond the most proximal portions of the bases. However, water immersion (fig. 4) reveals an outline of what clearly appears to be the propodus of the major chelipede. The proximal part of the segment is rather inflated, while the distal part of the pincer is thin and elongate. The "claw" is situated rather far back relative to the thorax and 

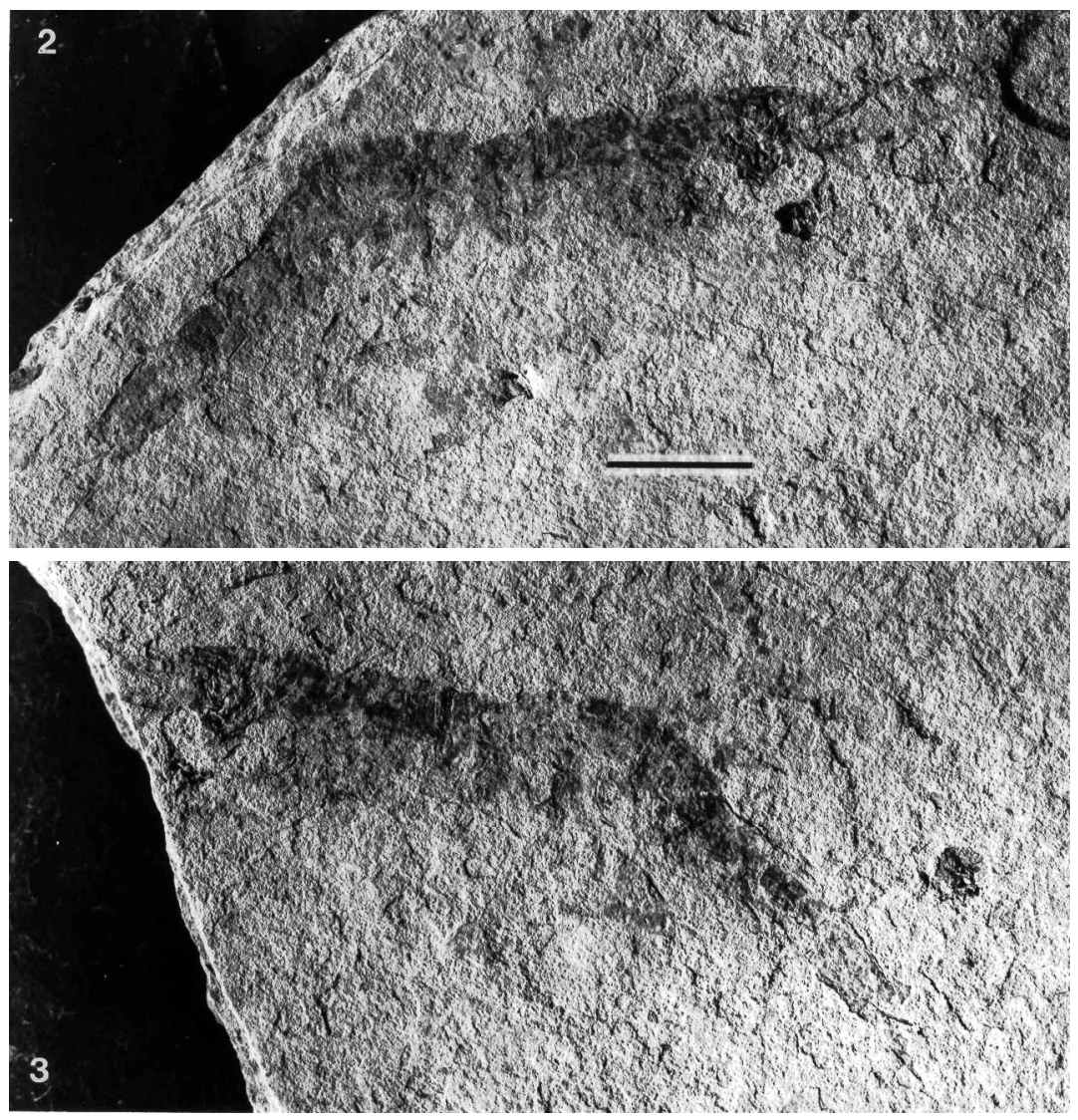

Figs. 2-3. Jilinocaris chinensis n. gen., n. sp. IGP no. 126268. 2, the holotype; 3, the lost counterpart (see text). Scale $=0.5 \mathrm{~cm}$.

thus appears to be associated not with the first pereiopod, as would be the case in a reptant decapod, but obviously with one of the middle pereiopods. It cannot be determined whether or not this is in fact the third pereiopod.

The abdomen is the best-preserved part of the body. The edges of the pleura of the first three pleomeres clearly bear thickened rims on their antero-ventral aspects. That of the first is sub-triangular. That of the second appears somewhat sub-quadrangular and has an anteriorly extending portion that overlaps the first. The third pleomere is the largest and bears an anteriorly broadly rounded extension overlapping the pleuron of the second segment. The main flexure point of the abdomen focuses between the second and third pleomeres. The fourth through sixth pleomeres appear to be narrower than any of the first three abdominal somites, and they either lacked, or had poorly developed, pleura. These last three segments appear to form a rather straight unit. Little of the pleopods remain except some 


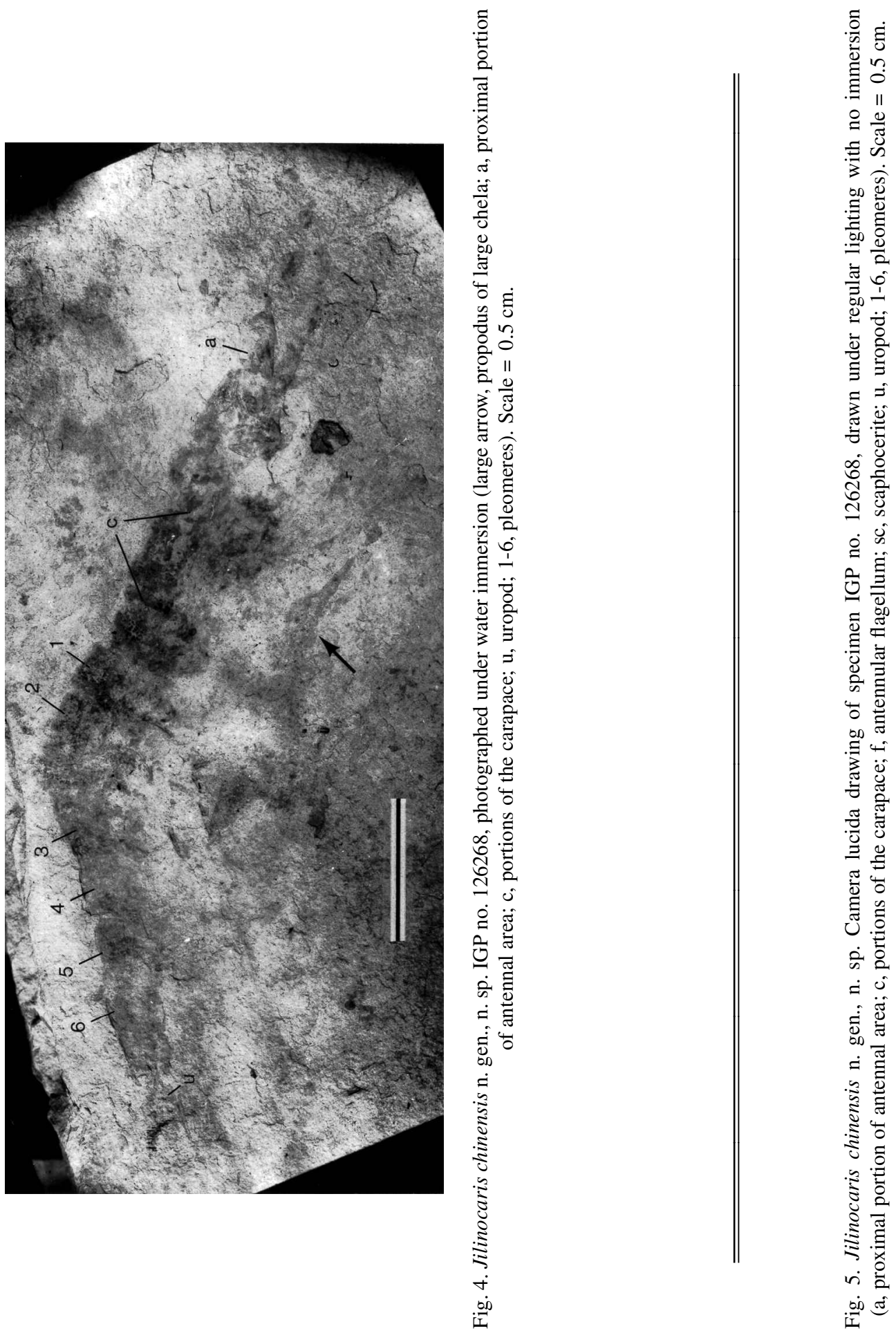


remnants of the protopods, but these seem to indicate rather large and welldeveloped limbs.

The uropodal protopod appears to have been serrate distally, while the exopod (?) of the uropod appears to have been long and well developed.

Remarks. - The specimen is not only incompletely preserved, it also appears to have been twisted. The cephalothorax is rather oblique in orientation, the anterior half of the abdomen seems to be veritably lateral, while the posterior half of the abdomen is almost a dorsal-ventral preservation. It would thus seem that the specimen is of either a molt, or possibly a decayed corpse in the initial stages of disintegration. This could explain why the specimen is so difficult to study.

Several pieces of "circumstantial evidence" combine to argue for probable stenopodidean affinities for Jilinocaris chinensis. These are as follows: (1) the rather well-developed, greatly elongate antennules and antennae; (2) the location of the principle claw of the pereiopods in the middle of the pereion; (3) a principle flexure of the abdomen in the vicinity of the third segment; and (4) the last three pleomeres forming a rather rigid unit (related perhaps to lock joints between the segments as seen in living forms). Any of these features separately would not be sufficient to define a stenopodidean, but taken together they form rather convincing arguments for such a higher taxonomic assignment.

As to which family of stenopodideans Jilinocaris chinensis belongs, we are less certain. The body does not seem to be greatly compressed laterally, but has the appearance of being rather shallow in lateral appearance. While the preservation is not particularly good for the only known specimen, the shallowness of the segments noted above might bespeak a dorso-ventrally depressed body form and thus place Jilinocaris closer to the Spongicolidae than the Stenopodidae. The anteriorly directed overlaps of the second and third pleomere pleura are distinctive for this species, especially the well-developed overlapping on the part of the third pleuron. These features might in fact argue for a separate familial status for this taxon. However, with only a single, incompletely preserved specimen with so little to clearly diagnose the species, we would hesitate to create a new family. For the time being we assign this species to the spongicolids.

The inferred palaeoecology of this taxon may eventually bear on the higher taxonomy of the species. All modern stenopodideans are temperate to tropical marine species. That the Nenjiang Formation appears to be a fresh-water deposit could prove vexing in this regard. However, some fossils in a few horizons within this formation are typical of brackish water, such as acritarchs and bivalves. Nevertheless, it would appear that the present stenopodidean probably lived in shallow fresh water based on the association with the well-preserved conchostracans. The poor preservation, however, of the single specimen of Jilinocaris chinensis relative 
to these conchostracans might also hold out the prospect for its transport into the area from possible adjacent brackish or marine habitats. Only a closer study of the geology and paleogeography of the region and the discovery of more specimens will allow these enigmas to be addressed.

\section{DISCUSSION}

Schram (1986) recognized two families within the Stenopodidea (see Holthuis, 1993, for a summary overview). The Stenopodidae have a laterally compressed body, the third maxilliped with an exopod, a long sub-triangular telson terminating in a pair of spines, and uropodal endopods with two longitudinal dorsal ridges. The Spongicolidae generally possess a depressed or somewhat depressed body form, the third maxilliped without or a rudimentary exopod, a rounded or subquadrangular telson terminating in 3 to 5 spines, and uropodal endopod with a single longitudinal dorsal ridge. It is obvious from these familial diagnoses that many of the truly pertinent characters that would allow a definitive placement of Jilinocaris chinensis will not be preserved in the fossils.

The higher taxonomic affinities of Stenopodidea Huxley, 1879 have shifted through time (Holthuis, 1993). Most recently, Burkenroad (1981) erected a separate suborder Euzygida to include the then single known family, the Stenopodidae, characterized by the lack of a hinge between the third and fourth pleomeres, the first pleopod with a reduced endopod, and an appendix interna usually on all pleopods. The Euzygida in Burkenroad's scheme stood in parallel with his resurrection (Burkenroad, 1963) of the taxon Eukyphida Boas, 1880 for the carideans, who together with stenopodideans share the apomorphic delayed appearance of the arthrobranchs in development. While Burkenroad (1981) viewed the carideans and euzygids as a single clade and as the sister group of the Reptantia, the modern consensus separates these two groups in a paraphyletic array within the Pleocyemata leading to the reptants (see Schram, in press, for a summary of the data).

Schram (1986) believed that the characterization of the Jurassic Uncinidea Beurlen, 1930 as possessing a very long first pereiopod (Glaessner, 1969) was wrong. The apparent location of the limb bearing the large claw on Uncinus posidoniae (Krause, 1891) is further back on the thorax than would be the case for a first pereiopod. This claw-bearing limb is probably located on the third or fourth pereiopod, and encouraged Schram (1986) to retain the use of Burkenroad's taxon Euzygida to unite Glaessner's infraorders Stenopodidea and Unicinidea. Thus, it will prove very important to see what more and better material of Jilinocaris chinensis will reveal relevant to the anatomy of the thorax. Clarifying the arrangement of the pereiopods will hopefully allow some evaluation of not only the status of Uncinus posidoniae in relation to the Stenopodidea, but also the now poorly understood relationships within the so-called Euzygida. 


\section{REFERENCES}

Burkenroad, M. D., 1963. The evolution of the Eucarida (Crustacea, Eumalacostraca) in relation to the fossil record. Tulane Studies in Geol., 2: 1-17.

— — 1981. The higher taxonomy and evolution of Decapoda (Crustacea). Trans. San Diego Soc. nat. Hist., 19: 251-268.

Glaessner, M. F., 1969. Decapoda. In: R. C. Moore (ed.), Treatise on invertebrate paleontology, R (Arthropoda) (4) (2): R400-R533. (Geol. Soc. America \& Univ. Kansas Press, Lawrence).

HAsiotis, S. T., in press. The origin and evolution of freshwater crayfish based on crayfish body and trace fossils. Freshwater Crayfish, 12.

Holthuis, L. B., 1993. The recent genera of the caridean and stenopodidean shrimps (Crustacea, Decapoda): with an appendix on the order Amphionidacea: 1-328. (Nationaal Natuurhistorisch Museum, Leiden).

Münster, G., 1839. Abbildung und Beschreibung der fossilen langschwänzigen Krebse in den Kalkschiefern von Bayern. Beiträge zur Petrefacten-Kunde, 2: 1-88, pls. 1-29.

Oppel, A., 1862. Ueber jurassische Crustaceen. Palaeontol. Mitt. a. d. Museum d. k. bayerischen Staates, 1: 1-120, pls. 1-38.

Schram, F. R., 1986. Crustacea: 1-606. (Oxford University Press, New York).

— - in press. The phylogeny of decapods: moving toward a consensus. Hydrobiol.

Schram, F. R., R. M. Feldmann \& M. J. Copeland, 1978. The Late Devonian Palaeopalaemonidae Brooks, 1962, and the earliest decapod crustaceans. Journ. Paleontol., 52: 1375-1387.

SChrAM, F. R. \& R. H. MAPES, 1984. Imocaris tuberculata, n. gen., n. sp. (Crustacea: Decapoda) from the Upper Mississippian Imo Formation, Arkansas. Trans. San Diego Soc. nat. Hist., 20: 165-168.

Zhang Wentang, Chen Peiji \& Shen Yanbin, 1976. Fossil Conchostraca of China: 1-325. (Science Press, Beijing).

First received 29 October 1999.

Final version accepted 3 December 1999. 